\title{
Teori Kritis dan Varian Paradigmatis dalam Ilmu Komunikasi
}

\author{
(AG. Eka Wenats Wuryanta)
}

\section{Pembuka Wacana}

Dalam sejarah keilmuan, wacana positivisme klasik sempat menjadi primadona paradigma dalam ilmu-ilmu sosial, termasuk di dalamnya ilmu komunikasi. Wacana positivisme yang dipelopori oleh para pemikir empirik radikal (pertama kali dicetuskan oleh Saint Simon pada tahun 1825) menjadi landasan epistemologi dalam menentukan kebenaran dalam ilmu sosial. August Comte dengan Sosiologi Positif menjadi paradigma pokok ilmu sosial yang berbasis pendekatan empirik sosial. Gugus ilmu sosial yang berkembang pada waktu itu menjadikan positivisme sebagai dominator rasionalitas dalam ilmu pengetahuan. Ini tentu saja dilandasi dengan pemikiran yang sudah berkembang pada waktu Renaissance dibuka sebagai swift epistemology dari epistemologi deduktif Platonik menjadi epistemologi induktif empirik Aristotelian yang semakin diradikalkan oleh Francis Bacon dalam induktivisme rasional.

Pada dasarnya, positivisme adalah jawaban alternatif dan tegas atas kegagalan filsafat spekulatif yang diradikalkan oleh filsafat Idealisme Jerman Immanuel Kant dan Filsafat Sejarah Hegel. Reaksi epistemologi ini lahir dari penolakan klaim kebenaran yang bersifat spekulatif dan jauh dari maksud sebenarnya dari pencarian kebenaran. Dalam perkembangan selanjutnya, positivisme mengalami modifikasi metodologis dan epistemologis yang sebenarnya juga menjauhi maksud sebenarnya pendekatan positif ditawarkan sebagai suatu sistem kebenaran.

Ilmu komunikasi dalam sejarah awal pembentukan juga tidak jauh dari kecenderungan positivisme ilmiah. Paradigma utama dalam ilmu komunikasi pun tidak jauh dari masalah metodologis yang bersifat empirik positif. Pendekatan mekanistik ala Shannon-Weaver tidak jauh melihat bahwa komunikasi merupakan pecahan mekanik yang dilakukan oleh manusia yang pada dasarnya meniru perilaku mesin transmitter dan receiver. Kecenderungan bahwa komunikasi merupakan proses linear mekanistik merupakan derivasi pemahaman ilmu alam dalam gugus perilaku manusiawi. Beberapa model pokok dalam ilmu komunikasi tidak jauh dari masalah distansi penuh antara peneliti dan yang diteliti, objektivistis-mekanistik, deduktif-nomonologis dan penelitian eksternal faktual dari setiap gejala yang masuk dalam perilaku komunikatif. Kecenderungan positivistik dalam ilmu komunikasi pun akhirnya membentuk bentuk ilmu sosial yang bersifat otoriter dan cenderung minuskecuali dalam 
memuaskan aturan dan sistem logika ketat yang menuntut pengujian korelasional yang dapat diuji secara praktis.

Kecenderungan dominan positivisme dalam ilmu komunikasi memberikan hasil model-model meta naratif pada pengalaman sosial manusia yang disebut dengan komunikasi. Meta narasi komunikasi yang bersifat universal mempunyai tantangan bahwa pola komunikasi sebenarnya sangat terikat dengan ruang dan waktu manusiawi. Padahal sifat keterikatan dengan ruang dan waktu ini bisa sangat bersifat tentatif dan relatif, mengingat sifat manusia yang bisa sangat kontekstual. Relasi komunikatif adalah kontekstual dalam arti bahwa relasi komunikatif tidak bisa begitu saja direduksi dalam pola kuantitatif yang bisa sangat rigid dengan keadaan yang sebenarnya.

Meta narasi universal dalam paradigma komunikasi pada suatu saat menimbulkan penyederhanaan pengalaman manusia yang bersifat tentatif. Tapi di lain waktu, meta narasi universal dalam paradigma komunikasi menimbulkan rejim otoriter dalam menentukan kebenaran yang bisa sangat bersifat manipulatif. Rejim otoriter ini menimbulkan masalah dogmatis dalam ilmu pengetahuan yang pada akhirnya mengakibatkan krisis epistemologis terutama dalam pendekatan rasional pada pengalaman manusia yang disebut dengan komunikasi.

Makalah ini memberikan gambaran singkat terhadap wacana alternatif terhadap pendekatan ilmu pengetahuan, terutama ilmu komunikasi. Ada perkembangan masyarakat yang tidak cukup dipahami dengan sederetan angka dan prosentase. Angka justru menimbulkan kesesatan pikir baru yang bersifat ideologis. Wacana alternatif tersebut adalah wacana teori kritis.

Hanya memang tulisan ini mencoba untuk mengembangkan diskusi teoritis tentang teori kritis dengan masalah bagaimana teori kritis dipahami dalam kerangka praksis.

\section{Diskusi 1. Sekilas tentang Teori Kritis}

Filsafat dan ilmu sosial abad XX diwarnai oleh empat pemikiran besar yaitu, fenomenologi-eksistensialisme, Neo-Thomisme, Filsafat Analitis dan aliran Neo Marxis (yang sering mengklaim dirinya sebagai pewaris tradisi Marxisme yang disesuaikan dengan keadaan jaman). Teori kritis, secara klasifikatif, dapat digolongkan pada kelompok yang terakhir. Meski dalam perdebatan filosofis, ada yang menganggap bahwa teori kritis adalah teori yang bukan marxis lagi.

Neo Marxisme adalah aliran pemikiran Marx yang menolak penyempitan dan reduksi ajaran Karl Marx oleh Engels. Ajaran Marx yang dicoba diinterpretasikan oleh Engels ini adalah versi inferpretasi yang nantinya sebagai "Marxisme" resmi. Marxisme Engels ini adalah versi interpretasi yang dipakai oleh Lenin. Interpretasi Lenin nanti pada akhirnya berkembang menjadi Marxisme-Leninisme (atau yang lebih dikenal dengan Komunisme). Beberapa tokoh neomarxisme sebetulnya pada akhirnya menolak marxisme-leninisme. Mereka menolak interpretasi Engels dan Lenin karena interpretasi tersebut adalah interpretasi ajaran Marx yang menghilangkan dimensi dialektika ala Karl Marx yang dipercaya sebagai salah satu bagian inti dari pemikiran Karl Marx. Tokoh neomarxisme adalah Georg Lukacs dan Karl Korsch, Ernst Bloch, Leszek Kolakowski dan Adam Schaff. 
Salah satu aliran pemikiran Kiri Baru yang cukup ternama adalah pemikiran Sekolah Frankfurt. Institut penelitian sosial di Frankfurt (Institut für Sozialforschung) didirikan pada tahun 1923 oleh seorang kapitalis yang bernama Herman Weil, seorang pedagang grosir gandum, yang pada akhir hayat "mencoba untuk cuci dosa" mau melakukan sesuatu untuk mengurangi penderitaan di dunia (termasuk dalam skala mikro: penderitaan sosial dari kerakusan kapitalisme).

Teori kritis adalah anak cabang pemikiran marxis dan sekaligus cabang marxisme yang paling jauh meninggalkan Karl Marx (Frankfurter Schule). Cara dan ciri pemikiran aliran Frankfurt disebut ciri teori kritik masyarakat "eine Kritische Theorie der Gesselschaft". Teori ini mau mencoba memperbaharui dan merekonstruksi teori yang membebaskan manusia dari manipulasi teknokrasi modern. Ciri khas dari teori kritik masyarakat adalah bahwa teori tersebut bertitik tolak dari inspirasi pemikiran sosial Karl Marx, tapi juga sekaligus melampaui bangunan ideologis marxisme bahkan meninggalkan beberapa tema pokok Marx dan menghadapi masalah masyarakat industri maju secara baru dan kreatif.

Beberapa tokoh Teori Kritis angkatan pertama adalah Max Horkheimer, Theodor Wiesengrund Adorno (musikus, ahli sastra, psikolog dan filsuf), Friedrich Pollock (ekonom), Erich Fromm (ahli psikoanalisa Freud), Karl Wittfogel (sinolog), Leo Lowenthal (sosiolog), Walter Benjamin (kritikus sastra), Herbert Marcuse (murid Heidegger yang mencoba menggabungkan fenomenologi dan marxisme, yang juga selanjutnya Marcuse menjadi “nabi” gerakan New Left di Amerika).

Teori Kritis menjadi disputasi publik di kalangan filsafat sosial dan sosiologi pada tahun 1961. Konfrontasi intelektual yang cukup terkenal adalah perdebatan epistemologi sosial antara Adorno (kubu Sekolah Frankfurt - paradigma kritis) dengan Karl Popper (kubu Sekolah Wina - paradigma neo positivisme/neo kantian). Konfrontasi berlanjut antara Hans Albert (kubu Popper) dengan Jürgen Habermas (kubu Adorno). Perdebatan ini memacu debat positivisme dalam sosiologi Jerman. Habermas adalah tokoh yang berhasil mengintegrasikan metode analitis ke dalam pemikiran dialektis Teori Kritis.

Pada awalnya, yang membedakan Teori Kritis dengan filsafat Heidegger atau filsafat analitika Ludwig Wittgenstein adalah Teori Kritis menjadi inspirasi dari gerakan sosial kemasyarakatan. Gerakan sosial ini dipelopori oleh kaum muda yang pada waktu itu secara historis telah tidak ingat lagi dengan masa kelaparan dan kedinginan pasca perang dunia II. Generasi muda tahun 1960-an telah merasa muak dengan kebudayaan yang menekankan pembangunan fisik dan menekankan faktor kesejahteraan ala kapitalisme. Generasi ini adalah generasi yang secara mendalam meragukan atau menyangsikan kekenyangan kapitalisme dan disorientasi nilai modern.

Yang merupakan ciri khas Teori Kritis adalah bahwa teori ini berbeda dengan pemikiran filsafat dan sosiologi tradisional. Pendekatan Teori Kritis tidak bersifat kontemplatif atau spektulatif murni. Teori Kritis pada titik tertentu memandang dirinya sebagai pewaris ajaran Karl Marx, sebagai teori yang menjadi emansipatoris. Teori Kritis tidak hanya mau menjelaskan, mempertimbangkan, merefleksikan dan menata realitas sosial tapi juga bahwa teori tersebut mau mengubah. Pada dasarnya, Teori Kritis mau menjadi praktis. 
Teori Kritis tidak mau membebek Karl Marx. Kelemahan marxisme pada umumnya adalah mereka menjiplak analisa Marx dan menerapkannya mentah-mentah pada masyarakat modern. Oleh sebab itu, biasanya marxisme justru lebih terkesan dogmatis daripada ilmiah. Teori Kritis mengadakan analisa baru terhadap masyarakat yang dipahami sebagai "masyarakat kapitalis lanjut". Yang direkonseptualisasi dalam pemikiran Teori Kritis adalah maksud dasar teori Karl Marx, yaitu pembebasan manusia dari segala belenggu penghisapan dan penindasan.

Pembebasan manusia dari segala belenggu penghisapan dan penindasan berangkat dari konsep kritik. Konsep kritik sendiri yang diambil oleh Teori Kritis berangkat dari 4 (empat sumber) kritik yang dikonseptualisasikan oleh Immanuel Kant, Hegel, Karl Marx dan Sigmund Freud. Kritik dalam pengertian pemikiran Kantian adalah kritik sebagai kegiatan menguji kesahihan klaim pengetahuan tanpa prasangka. Kritik dalam pengertian Hegel didefinisikan sebagai refleksi diri atas tekanan dan kontradiksi yang menghambat proses pembentukan diri-rasio dalam sejarah manusia. Kritik dalam pengertian Marxian berarti usaha untuk mengemansipasi diri dari alienasi atau keterasingan yang dihasilkan oeh hubungan kekuasaan dalam masyarakat. Kritik dalam pengertian Freudian adalah refleksi atas konflik psikis yang menghasilkan represi dan memanipulasi kesadaran. Adopsi Teori Kritis atas pemikiran Freudian yang sangat psikologistik dianggap sebagai pengkhianatan terhadap ortodoksi marxisme klasik.

\section{Diskusi 2: Pengaruh Teori Kritis dalam Wacana Ilmu Komunikasi}

Pertemuan pertama Teori Kritis dengan ilmu komunikasi sebenarnya terjadi ketika Teori Kritis berimigrasi ke Amerika Serikat. Perkembangan ilmu komunikasi di Amerika sudah mengalami perkembangan yang pesat. Premis awal IImu komunikasi di Amerika merupakan pernik awal perkembangan teknologi informasi bahkan sebelum perang dunia I. Perkembangan ilmu komunikasi di Amerika banyak ditandai dengan perkembangan komunikasi massa di negara tersebut. Sementara itu, paradigma dominan ilmu komunikasi dipenuhi dengan paradigma positivistik.

Teori Kritis yang dibawa oleh para sarjana Jerman akhirnya berpindah di beberapa universitas di Amerika pada tahun 1933. Tentu saja, pertemuan dua tradisi intelektual tersebut menghasilkan kontroversi. Paradigma kritis yang sangat kritis idealistik bertemu dengan tradisi keilmuan yang pragmatis. Dalam sejarah perkembangannya, penelitian komunikasi di Amerika dipengaruhi oleh kondisi sejarah sosial, politik dan budaya yang terjadi. Komunikasi pada titik tertentu, di Amerika, berada dalam titik pragmatik yang sangat komersial dan memunculkan diskursus klasik terhadap perubahan sosial, terutama yang berkaitan dengan arus kesejahteraan yang bersifat kapitalistik.

Ide pragmatisme sangat mewarnai penelitian komunikasi di Universitas Chicago yang kajiannya sangat empirik. Paul Lazarfeld, Kurt Lewin, Harold Laswell dan Carl Hovland. Studi yang dikembangkan oleh Wilbur Schramm adalah studi kuantitatif dalam konteks anthropologi komunikasi.

Kontribusi kritisisme Teori Kritis dikembangkan oleh Adorno yang mengkritik pendekatan Paul Lazarfeld yang sangat dipengaruhi oelh pendekatan struktural fungsionalistik ala Talcott Parsons. Horkheimer dan Adorno melihat cacat epistemologi dalam ilmu komunikasi yang berwatak totaliter 
dan ideologis. Teori Kritis melihat bahwa ada kecenderungan di kalangan ilmuwan komunikasi menjadi ilmu ini untuk dipaksakan dalam wujud ilmu yang sangat mekanistik. Model pemikiran administratif yang dikembangkan oleh pemikir Universitas Chicago dikritisi oleh model pemikiran kritis.

Riset komunikasi yang berkembang bersamaan dengan asumsi pemikiran administratif adalah riset studi efek media massa. Selanjutnya dalam era 30-40-an pemikiran Teori Kritis mengembangkan studi tentang ekonomi politik media, analisis budaya atas teks, dan studi resepsi khalayak - studi ideologi dalam media yang pada akhirnya mengalami perkembangan yang pesat pada era 70-80-an.

Pendekatan ekonomi politik memfokuskan pada kajian utama tentang hubungan antara struktur ekonomi-politik, dinamika industri media, dan ideologi media itu sendiri. Perhatian penelitian ekonomi politik diarahkan pada kepemilikan, kontrol serta kekuatan operasional pasar media. Dari titik pandang ini, institusi media massa dianggap sebagai sistem ekonomi yang berhubungan erat dengan sistem politik.

Perspektif ekonomi politik kritis juga menganalisa secara penuh pada campur tangan publik sebagai proses legitimasi melalui ketidaksepakatan publik atas bentuk-bentuk yang harus diambil karena adanya usaha kaum kapitalis mempersempit ruang diskursus publik dan representasi. Dalam konteks ini dapat juga disebut adanya distorsi dan ketidakseimbangan antara masyarakat, pasar dan sistem yang ada. Sedangkan kriteria-kriteria yang dimiliki oleh analisa ekonomi politik kritis terdiri dari tiga kriteria. Kriteria pertama adalah masyarakat kapitalis menjadi kelompok (kelas) yang mendominasi. Kedua, media dilihat sebagai bagian dari ideologis di mana di dalamnya kelas-kelas dalam masyarakat melakukan pertarungan, walaupun dalam konteks dominasi kelas-kelas tertentu. Kriteria terakhir, profesional media menikmati ilusi otonomi yang disosialisasikan ke dalam norma-norma budaya dominan.

Perspektif ekonomi-politik kritis memiliki tiga varian utama. Ketiga varian tersebut adalah instrumentalisme, kulturalisme, dan strukturalisme. Dalam penelitian ini, varian yang digunakan adalah perspektif instrumentalisme. Perspektif ini memberikan penekanan pada determinisme ekonomi, di mana segala sesuatu pada akhirnya akan dikaitkan secara langsung dengan kekuatan-kekuatan ekonomi. Perspektif ini melihat media sebagai instrumen dari kelas yang mendominasi. Dalam hal ini kapitalis dilihat sebagai pihak yang menggunakan kekuatan ekonominya untuk kepentingan apapun - dalam sistem pasar komersial untuk memastikan bahwa arus informasi publik sesuai dengan kepentingannya.

Studi Kajian Budaya Kritis juga menempatkan media sebagai salah satu aktor budaya dalam melakukan imperialisme budaya. Aktor budaya dalam konteks ini adalah konteks ideologi dominan maka media menjadi ideological apparatus.

Studi resepsi kritis menempatkan bahwa kelompok khalayak terbagi dalam klasifikasi status sosial dan ekonomi. Secara politis, masyarakat terbagi dalam kelompok sosial yang mempunyai tingkat resepsi yang berbeda. Pendekatan Bordieu banyak memakai metode ini. 
Diskusi 3. Penerapan Aplikatif: Wacana Media, Ideologi Dan Hegemoni

Media dalam konteks Teori Kritis selalu berhubungan dengan ideologi dan hegemoni. Hal ini berkaitan dengan cara bagaimana sebuah realitas wacana atau teks ditafsirkan dan dimaknai dengan cara pandang tertentu.

Pendapat Golding dan Murdock (Currant \& Guravitch ed., 1991:188) menunjukkan bahwa studi wacana media meliputi tiga wilayah kajian, yaitu teks itu sendiri, produksi dan konsumsi teks. Kerangka teoritis semacam ini adalah kerangka teoritis yang senada dikembangkan oleh Norman Fairclough. Perbedaan analisis Golding dan Murdock jika dibandingkan dengan analisis wacana kritis Norman Fairclough terletak pada wilayah analisis teks, produksi dan konsumsi sebagai kajian tersendiri. Fairclough mempunyai kerangka teks, praktek wacana dan praktek sosial budaya sebagai wilayah analisis kritisnya. Dari konteks perspektif analisis di atas maka teks ditafsirkan.

Wacana teks selalu melibatkan dengan apa yang disebut dengan alternasi atau peralihan timbal balik antara dua fokus kembar analisis wacana, yaitu kejadian komunikatif (teks, praktek wacana dan praktek sosial budaya) dengan tatanan wacana (genre dan jenis pewacanaan).

Kejadian komunikatif meliputi aspek teks, praktek wacana dan praktek sosial budaya. Wilayah teks media merupakan representasi yang berkaitan dengan realitas produksi dan konsumsi. Fairclough melihat bahwa wilayah teks merupakan wilayah analisis fungsi representasional-interpersonal teks dan tatanan wacana. Fungsi representasional teks menyatakan bahwa teks berkaitan dengan bagaimana kejadian, situasi, hubungan dan orang yang direpresentasikan dalam teks. Ini berarti bahwa teks media bukan hanya sebagai cermin realitas tapi juga membuat versi yang sesuai dengan posisi sosial, kepentingan dan sasaran yang memproduksi teks. Fungsi interpersonal adalah proses yang berlangsung secara simultan dalam teks.

Wacana untuk konsumsi publik bukan dilihat dalam keadaan mentah tapi sebaliknya wacana dalam konteks publik adalah wacana yang diorganisasi ulang dan dikontekstualisasikan agar sama dengan bentuk ekspresi tertentu yang sedang digunakan. Bentuk ekspresi teks tertentu mempunyai dampak besar atau apa yang terlihat, siapa yang melihat dan dari perspektif sudut pandang macam apa.

Wacana teks media juga membutuhkan analisis intertekstualitas. Analisis ini lebih ingin mengetahui hubungan antara teks dengan praktek wacana. Intertekstualitas ini bisa berproses dalam cara-cara pemaduan genre dan pewacanaan yang tersedia dalam tatanan wacana untuk produksi dan konsumsi teks. Selain itu, analisis ini juga ingin melihat cara transformasi dan relasi teks satu dengan teks yang lain. Dalam perspektif ekonomi politik kritis, analisis ini memperlihatkan proses komodifikasi dan strukturasi.

Pemaknaan dan makna tidak an sich ada dalam teks atau wacana itu sendiri (Fiske, 1988:143-144). Hal ini bisa dijelaskan bahwa ketika kita membaca teks, maka makna tidak akan kita temukan dalam teks yang bersangkutan. Yang kita temukan adalah pesan dalam sebuah teks. Sebuah peristiwa yang direkam oleh media massa baru mendapat makna ketika peristiwa tersebut ditempatkan dalam 
identifikasi kultural di mana berita tersebut hadir. Peristiwa demi peristiwa diatur dan dikelola sedemikian rupa oleh para awak media, dalam hal ini oleh para wartawan. Itu berarti bahwa para awak media menempatkan peristiwa ke dalam peta makna. Identifikasi sosial, kategorisasi, dan kontekstualisasi dari peristiwa adalah proses penting di mana peristiwa itu dibuat bermakna bagi khalayak.

Para awak media dalam konteks pemberitaan teks media selalu memperhatikan aspek konsensus sosial. Meskipun demikian, pemahaman awak media terhadap suatu proses produksi media sangat dipengaruhi oleh proses pengolahan peta ideologi pada setiap awak media, dalam hal ini adalah wartawan.

\section{Diskusi 4. Penerapan Aplikatif: Paradigma Kritis Dan Wacana Teks Media}

Penelitian media massa lebih diletakkan dalam kesadaran bahwa teks atau wacana dalam media massa mempunyai pengaruh yang sedemikian rupa pada manusia (Littlejohn, 2002: 163-183). Seluruh aktivitas dan pemaknaan simbolik dapat dilakukan dalam teks media massa. Pada dasarnya teks media massa bukan realitas yang bebas nilai. Pada titik kesadaran pokok manusia, teks selalu memuat kepentingan. Teks pada prinsipnya telah diambil sebagai realitas yang memihak. Tentu saja teks dimanfaatkan untuk memenangkan pertarungan idea, kepentingan atau ideologi tertentu kelas tertentu. Pada titik tertentu, teks media pada dirinya sudah bersifat ideologis (Littlejohn, 2002:217).

Pembahasan yang harus disadari adalah bukan hanya terletak bahwa teks media selalu bersifat ideologis tapi terutama adalah kemampuan untuk membedakan antara kuasa teks itu sendiri dengan kuasa struktur makro yang secara sengaja atau tidak sengaja merekonstruksi, merepresentasikan dan memaknai teks tersebut (Shoemaker \& Reese, 1991: 53-205). Dalam arti bahwa, meski konsumen dan produsen teks media punya opsi bagaimana teks harus disimbolisasikan dan dimaknai tetap saja ada bingkai aktivitas dan opsi mereka yang terbentuk dan dipengaruhi oleh faktor yang berada di luar jangkauan kendali sadar konsumen atau produsen teks media.

Pengenalan dan pemahaman yang cukup komprehensif atas struktur sistem produksi media, rasionalitas dan ideologi yang berada di balik teks media yang bersangkutan menjadi hal yang penting. Diperlukan paradigma penelitian dan metode penelitian yang mampu menelanjangi, menggali dan mengeksplorasi struktur, rasionalitas dan ideologi yang kesemuanya bersifat laten termuat dalam sebuah teks media (Dedy N. Hidayat, 2000: 127-164).

\section{Diskusi 5: Penerapan Aplikatif: Wacana Media, Paradigma Dan Teori Kritis}

IImu komunikasi dapat dikategorikan dalam ilmu pengetahuan yang mempunyai aktivitas penelitian yang bersifat multi paradigma. Ini berarti, ilmu komunikasi merupakan bidang ilmu yang menampilkan sejumlah paradigma atau perspektif dasar pada waktu bersamaan (Hidayat, 1999:431-446). Istilah paradigma sendiri dapat didefinisikan sebagai:

"a set of basic beliefs (or metaphysics) that deals with ultimates or first principles... a world view that defines, for its holder, the nature of the 'world'...(Guba, dalam Denzin \& Lincoln, 1994:107). 
Paradigma merupakan orientasi dasar untuk teori dan riset. Pada umumnya suatu paradigma keilmuan merupakan sistem keseluruhan dari berfikir. Paradigma terdiri dari asumsi dasar, teknik riset yang digunakan, dan contoh seperti apa seharusnya teknik riset yang baik (Newman, 1997:62-63).

Terlepas dari segala variasinya, perbedaan antara paradigma yang satu dengan paradigma yang lain dapat dikelompokkan berdasarkan hal yang mendasar. Hal-hal tersebut adalah hal yang berkaitan dengan konsep dan ide dasar ilmu sosial, atau asumsi-asumsi tentang masyarakat, manusia, realitas sosial, opsi moral, serta komitmen terhadap nilai-nilai tertentu.

Setidaknya ada empat paradigma yang bisa dikelompokkan dalam teori-teori penelitian ilmiah komunikasi. Paradigma-paradigma itu adalah sebagai berikut paradigma humanis radikal (radical humanist paradigm), paradigma struktural radikal (radical structuralist paradigm), paradigma interpretif (Interpretive paradigm), dan terakhir adalah paradigma fungsionalis (fungsionalist paradigm).

Guba \& Lincoln (1994:17-30) juga menyusun beberapa paradigma dalam teori ilmu komunikasi. Paradigma yang dikemukakan itu terdiri dari paradigma positivistik, paradigma pospositivistik, paradigma kritis, dan paradigma konstruktivisme. Beberapa ahli metodologi dalam bidang ilmu sosial berpendapat bahwa paradigma positivistik dan pospositivistik merupakan kesatuan paradigma, yang sering disebut dengan paradigma klasik. Implikasi metodologis dan teknis dari dua paradigma tersebut, dalam prakteknya, tidak punya banyak perbedaan. Adanya konstelasi paradigma di atas maka teori dan penelitian biasa dikelompokkan dalam tiga paradigma utama, yaitu paradigma klasik, paradigma kritis dan paradigma konstruktivisme. Apabila terjadi tiga pembedaan paradigma dalam ilmu sosial, maka terjadi perbedaan pemahaman terhadap paradigma itu sendiri.

Perbedaan antara ketiga paradigma ini juga dapat dibahas dari 4 (empat) dimensi. Keempat dimensi tersebut adalah dimensi epistemologis, dimensi ontologis, dimensi metodologis, serta dimensi aksiologis.

Dimensi epistemologis berkaitan dengan asumsi mengenai hubungan antara peneliti dengan yang diteliti dalam proses memperoleh pengetahuan mengenai objek yang diteliti. Seluruhnya berkaitan dengan teori pengetahuan (theory of knowledge) yang melekat dalam perspektif teori dan metodologi.

Dimensi ontologis berhubungan dengan asumsi mengenai objek atau realitas sosial yang diteliti. Dimensi metodologis mencakup asumsi-asumsi mengenai bagaimana cara memperoleh pengetahuan mengenai suatu obyek pengetahuan. Sedangkan dimensi aksiologis berkaitan dengan posisi value judgments, etika serta pilihan moral peneliti dalam suau penelitian.

Paradigma kritis pada dasarnya adalah paradigma ilmu pengetahuan yang meletakkan epistemologi kritik Marxisme dalam seluruh metodologi penelitiannya. Fakta menyatakan bahwa paradigma kritis yang diinspirasikan dari teori kritis tidak bisa melepaskan diri dari warisan Marxisme dalam seluruh filosofi pengetahuannya. Teori kritis pada satu pihak merupakan salah satu aliran ilmu sosial yang berbasis pada ide-ide Karl Marx dan Engels (Denzin, 2000: 279-280). 
Pengaruh idea marxisme - neo marxisme dan teori kritis mempengaruhi filsafat pengetahuan dari paradigma kritis. Asumsi realitas yang dikemukakan oleh paradigma adalah asumsi realitas yang tidak netral namun dipengaruhi dan terikat oleh nilai serta kekuatan ekonomi, politik dan sosial. Oleh sebab itu, proyek utama dari paradigma kritis adalah pembebasan nilai dominasi dari kelompok yang ditindas. Hal ini akan mempengaruhi bagaimana paradigma kritis memcoba membedah realitas dalam penelitian ilmiah, termasuk di dalamnya penelitian atau analisis kritis tentang teks media. Ada beberapa karakteristik utama dalam seluruh filsafat pengetahuan paradigma kritis yang bisa dilihat secara jelas.

Ciri pertama adalah ciri pemahaman paradigma kritis tentang realitas. Realitas dalam pandangan kritis sering disebut dengan realitas semu. Realitas ini tidak alami tapi lebih karena bangun konstruk kekuatan sosial, politik dan ekonomi. Dalam pandangan paradigma kritis, realitas tidak berada dalam harmoni tapi lebih dalam situasi konflik dan pergulatan sosial (Eriyanto, 2001:3-46).

Ciri kedua adalah ciri tujuan penelitian paradigma kritis. Karakteristik menyolok dari tujuan paradigma kritis ada dan eksis adalah paradigma yang mengambil sikap untuk memberikan kritik, transformasi sosial, proses emansipasi dan penguatan sosial. Dengan demikian tujuan penelitian paradigma kritis adalah mengubah dunia yang tidak seimbang. Dengan demikian, seorang peneliti dalam paradigma kritis akan mungkin sangat terlibat dalam proses negasi relasi sosial yang nyata, membongkar mitos, menunjukkan bagaimana seharusnya dunia berada (Newman, 2000:75-87; Denzin, 2000:163-186).

Ciri ketiga adalah ciri titik perhatian penelitian paradigma kritis. Titik perhatian penelitian paradigma kritis mengandaikan realitas yang dijembatani oleh nilai-nilai tertentu. Ini berarti bahwa ada hubungan yang erat antara peneliti dengan objek yang diteliti. Setidaknya peneliti ditempatkan dalam situasi bahwa ini menjadi aktivis, pembela atau aktor intelektual di balik proses transformasi sosial. Dari proses tersebut, dapat dikatakan bahwa etika dan pilihan moral bahkan suatu keberpihakan menjadi bagian yang tak terpisahkan dari analisis penelitian yang dibuat.

Karakteristik keempat dari paradigma kritis adalah pendasaran diri paradigma kritis mengenai cara dan metodologi penelitiannya. Paradigma kritis dalam hal ini menekankan penafsiran peneliti pada objek penelitiannya. Hal ini berarti ada proses dialogal dalam seluruh penelitian kritis. Dialog kritis ini digunakan untuk melihat secara lebih dalam kenyataan sosial yang telah, sedang dan akan terjadi.

Dengan demikian, karakteristik keempat ini menempatkan penafsiran sosial peneliti untuk melihat bentuk representasi dalam setiap gejala, dalam hal ini media massa berikut teks yang diproduksinya. Maka, dalam paradigma kritis, penelitian yang bersangkutan tidak bisa menghindari unsur subjektivitas peneliti, dan hal ini bisa membuat perbedaan penafsiran gejala sosial dari peneliti lainnya (Newman, 2000:63-87).

Dalam konteks karakteristik yang keempat ini, penelitian paradigma kritis mengutamakan juga analisis yang menyeluruh, kontekstual dan multi level. Hal ini berarti bahwa penelitian kritis menekankan soal historical situatedness dalam seluruh kejadian sosial yang ada (Denzin, 2000:170). 
Perkembangan teori kritis semakin jelas ketika Sekolah Frankfurt menjadi motor penggerak teori tersebut. Selain bahwa Sekolah Frankfurt bersentuhan dengan perkembangan ilmu sosial kritis pada waktu itu, Sekolah tersebut juga merefleksikan peran media massa pada masyarakat waktu itu. Tentu saja, konteks Jerman pada waktu itu juga sangat dipengaruhi oleh sejarah Jerman pada waktu pemerintahan Hitler (Nazi).

Dalam perkembangan selanjutnya, Sekolah Frankfurt juga menyatakan bahwa ternyata media bisa menjadi alat pemerintah untuk mengontrol publik, dalam arti tertentu media bisa menjadi bagian dari ideological state apparatus (Littlejohn, 2002:213). Dalam hal tertentu, media bukan adalah realitas yang netral dan bebas kepentingan, tapi media massa justru menjadi realitas yang rentan dikuasai oleh kelompok yang lebih dominan dan berkuasa (Rogers, 1994:102-125).

Asumsi dasar dalam paradigma kritis berkaitan dengan keterangan di atas adalah keyakinan bahwa ada kekuatan laten dalam masyarakat yang begitu berkuasa mengontrol proses komunikasi masyarakat. Ini berarti paradigma kritis melihat adanya "realitas" di balik kontrol komunikasi masyarakat. Masalahnya siapa yang mempunyai kekuatan kontrol tersebut? Mengapa mengontrol ? Ada kepentingan apa ? Dengan beberapa kalimat pertanyaan itu, terlihat bahwa teori kritis melihat adanya proses dominasi dan marginalisasi kelompok tertentu dalam seluruh proses komunikasi masyarakat. Hal ini menyatakan bahwa proses penyebaran dan aktivitas komunikasi massa juga sangat dipengaruhi oleh struktur ekonomi politik masyarakat yang bersangkutan.

Proses pemberitaan tidak bisa dipisahkan dengan proses politik yang berlangsung dan akumulasi modal yang dimanfaatkan sebagai sumber daya. Ini merupakan proses interplay, di mana proses ekonomi politik dalam media akan membentuk dan dibentuk melalui proses produksi, distribusi dan konsumsi media itu. Ini berarti bahwa apa yang terlihat pada permukaan realitas belum tentu menjawab masalah yang ada. Apa yang nampak dari permukaan harian belum tentu mewakili kebenaran realitas itu sendiri. Teori kritis pada akhirnya selalu mengajarkan kecurigaan dan cenderung selalu mempertanyakan realitas yang ditemui, termasuk di dalamnya teks media itu sendiri.

Paradigma kritis tidak cukup puas pada jawaban, pola, struktur, simbol dan makna yang tersedia. Perlu ada pemaknaan yang lebih komprehensif dan kritis atas media yang ada. Beberapa keyakinan teori kritis menjadi acuan awal pemahaman kita terhadap studi teks media dalam konteks paradigma kritis.

Teori kritis melihat bahwa media tidak lepas kepentingan, terutama sarat kepentingan kaum pemilik modal, negara atau kelompok yang menindas lainnya. Dalam artian ini, media menjadi alat dominasi dan hegemoni masyarakat. Konsekuensi logisnya adalah realitas yang dihasilkan oleh media bersifat pada dirinya bias atau terdistorsi.

Selanjutnya, teori kritis melihat bahwa media adalah pembentuk kesadaran. Representasi yang dilakukan oleh media dalam sebuah struktur masyarakat lebih dipahami sebagai media yang mampu memberikan konteks pengaruh kesadaran (manufactured consent). Dengan demikian, media 
menyediakan pengaruh untuk mereproduksi dan mendefinisikan status atau memapankan keabsahan struktur tertentu. Inilah sebabnya, media dalam kapasitasnya sebagai agen sosial sering mengandaikan juga praksis sosial dan politik.

Pendefinisian dan reproduksi realitas yang dihasilkan oleh media massa tidak hanya dilihat sebagai akumulasi fakta atau realitas itu sendiri. Reproduksi realitas melalui media merupakan representasi tarik ulur ideologi atau sistem nilai yang mempunyai kepentingan yang berbeda satu sama lain. Dalam hal ini, media tidak hanya memainkan perannya hanya sekedar instrumen pasif yang tidak dinamis dalam proses rekonstruksi budaya tapi media massa tetap menjadi realitas sosial yang dinamis.

Reproduksi realitas dalam media pada dasarnya dan umumnya akan sangat dipengaruhi oleh bahasa (Littlejohn, 2002:210-211), simbolisasi pemaknaan dan politik penandaan. Bahasa di samping sebagai realitas sosial, tetap bisa dilihat sebagai sebuah sistem penandaan. Sistem penandaan dalam arti bahwa bahasa atau suatu realitas yang ingin menandakan realitas lainnya (peristiwa atau pengalaman hidup manusia).

Dengan demikian, sebuah realitas dapat ditandakan secara berbeda pada peristiwa yang sama. Atau, dapat dikatakan bahwa pemaknaan yang tidak sama bisa dilekatkan kepda peristiwa yang sama. Masalah terjadi ketika suatu makna yang ditafsirkan dan dikonstruksi ulang oleh kelompok tertentu dari peristiwa yang sama tersebut cenderung mendominasi penafsiran. Bagaimana mungkin sebuah makna tertentu bisa lebih unggul dan lebih diterima dibandingkan pemaknaan lainnya ?

Mengapa pemaknaan lain di luar pemaknaan yang sudah ditentukan justru dimarginalisasikan ? Dengan kata lain, bahwa sesungguhnya ketika kita melihat proses bahasa dan pemaknaan, sebetulnya kita juga melihat ranah atau wilayah pertarungan sosial (Stuart Hall, 1982:80). Pertarungan sosial tersebut lebih konkret terbentuk dalam sebuah wacana serta terartikulasikan dalam proses pembentukan dan praksis bahasa.

Kedua, bahasa dalam konteks wacana - terutama dalam konteks wacana komunikasi - sebetulnya mencakup pengiriman pesan dari sistem syaraf satu orang kepada yang lain, dengan maksud untuk menghasilkan sebuah makna sama dengan yang ada dalam benak si pengirim (Tubs \& Moss, 1994: 66). Pesan verbal selalu memakai kata. Kata selalu merujuk pada keberadaan sebuah bahasa. Ini berarti kita sepakat bahwa kita menggunakan simbol bahasa dalam aktivitas komunikasi.

Dalam perkembangan ilmu komunikasi modern, bahasa adalah kombinasi kata yang diatur dan dikelola secara sistematis dan logis sehingga bisa dimanfaatkan sebagai alat komunikasi. Dengan demikian, kata merupakan bagian integral dari keseluruhan simbol yang dibuat oleh suatu kelompok tertentu. Jadi, kata selalu bersifat simbolik. Simbol dapat diartikan sebagai realitas yang mewakili atau merepresentasikan idea, pikiran, gagasan, perasaan, benda atau tindakan manusia yang dilakukan secara arbitrer, konvensional dan representatif-intrepretif. Oleh sebab itu, tidak ada hubungan yang berlaku secara alamiah dan selalu bersifat koresponden antara simbol dengan realitas yang disimbolkan. 
Ketiga, politik penandaan lebih banyak bermakna pada soal bagaimana praksis sosial pembentukan makna, kontrol dan penentuan suatu makna tertentu. Peran media massa dalam praksis sosial penentuan tanda dan makna tidak melepaskan diri dari proses kompetisi ideologi. Relasi dominasi dan kompetisi ideologis tidak hanya berproses pada tataran aparatur kelompok dominan saja tapi juga melalui produksi dan reproduksi kekuasaan yang berada dalam ruang budaya - tempat di mana makna hidup disusun. Pada proses inilah, terungkap bahwa produksi - konstruksi realitas menghubungkan dimensi politik wacana dengan dimensi politik ruang (M.Shapiro, 1992: 1-6). Hal ini disebabkan bahwa hanya dalam ruang tertentu saja praksis wacana yang lahir dari sejarah dominasi dan kompetisi kultur yang panjang hingga dimenangkannya kompetisi oleh kekuatan paling dominan dan hegemonis yang pada gilirannya menentukan rekayasa politik wacana. 


\section{Daftar Pustaka}

Berger, Arthur Asa. 1991. Media Analysis Techniques. California:Sage Publication

Bignell, Jonathan. 2001. Media Semiotics, An Introduction. London: Manchaster University Press

Chomsky, Noam dan Edward S. Herman, 1988. Manufacturing Consent: The Political Economy of the Mass Media. New York:Pantheon

Currant, James and Michael Gurevitch. 1991. Mass Media and Society .London :Edward Arnold

Curran, James and Richard Collins, 1986. Media, Culture and Society: A Critical Reader. London:Sage Publication

Denzin, Norman K. (eds). 2000. Handbook of Qualitative Research. California:Sage Public

Eriyanto. 2001. Analisis Wacana: Pengantar Analisa Teks Media. Yogyakarta:LKIS

Fairclough, Norman. 1998. Critical Discourse Analysis: The Critical Study of Language. London:Longman

Fairclough, Norman. 1995. Media Discourse. New York:Edward Arnold

Fiske, John. 1982. Introduction of Communication Studies. London:Routledge

Guba, Egon. G,. 1990. The Paradigm Dialog. New York:Sage Books

Hall, Stuart. 1992. Culture, Media dan Language. London:Routledge

Hardiman, Budi Francisco, 1990. Kritik Ideologi: Pertautan Pengetahuan dan Kepentingan. Yogyakarta:Kanisius

Kolakowski, Leszek. 1978. Main Currents of Marxisme III. Oxford:Clarendon Press

Latif, Yid dan Idi Subandy Ibrahim (eds). 1996. Bahasa dan Kekuasaan: Politik Wacana di Panggung Orde Baru.Jakarta:Mizan

Littlejohn, Stephen. 2002. Theories of Human Communication. California:Wadsworth Publishing Company

Lull, James. 1998. Media, Komunikasi, Kebudayaan; Suatu Pendekatan Global. Jakarta:YOI

Magnis-Suseno, Franz. 1992. Filsafat sebagai Ilmu Kritis. Yogyakarta:Kanisius

Magnis-Suseno, Franz. 1991. Etika Politik: Prinsip-prinsip Moral dan Dasar Kenegaraan modern. Jakarta:Gramedia

Mannheim, Karl. 1979. Ideologi dan Utopia. An Introduction to the Sociology of Knowledge. London:Routledge

Mcdonnell, Diane. 1986. Theories of Discourse: An Introduction. Oxford:Basil Blackwall 
Mcquail, Dennis (ed). 2002. McQuail's Reader in Mass Communication Theory. London:Sage Publications

Mills, Sara. 1991. Discourse. London:Routledge

Neuman, Lawrence W. 2000. Social Research Methods. London:Allyn and Bacon

Raboy, Marc dan Bernard Dagenais (eds). 1995. Media, Crisis and Democracy: Mass Communication and the Disruption of Social Order. London:Sage Publication

Reese, Stephen D,. 2001. Framing Public Life. New Jersey:Lawrence Earlbaum Publisher

Riggins, Stephen H,. 1997. The Language and Politics of Exclusion: Others in Discourse. London:Sage Publication

Rogers, Everett. M. 1994. A History of Communication Study. New York:The Free Press

Saverin, Werner. 1997. Communication Theories: Origins, Methods and Uses in the Mass Media. New York:Longman

Sen, Krishna dan David T. Hill. 2001. Media, Budaya dan Politik di Indonesia. Jakarta:PT Media Lintas Inti Nusantara

Shoemaker, Pamela cs (eds). 1991. Mediating The Message: Theories of Influences on Mass Media Content. London:Longman Group

Shoemaker, Pamela cs (eds). 1996. Mediating The Message: Theories of Influences on Mass Media Content. London:Longman Group

Sobur, Alex. 2001. Analisis Teks Media: Suatu Pengantar untuk Analisis Wacana, Analisis Semiotik, dan Analisis Framing. Bandung:PT. Remaja Rosdakarya

Wimmer, Roger D. 2000. Mass Media Research: An Introduction. Singapore:Wadsworth PC

Vatikionis, Michail R.J. 1993. Indonesian Politics under Soeharto, Order, Development and Pressure for Change. New York:Routledge 